\title{
Prostaglandin Signaling Governs Spike Timing-Dependent Plasticity at Sensory Synapses onto Mouse Spinal Projection Neurons
}

\author{
- \\ Pain Research Center, Department of Anesthesiology, University of Cincinnati Medical Center, Cincinnati OH 45267
}

Highly correlated presynaptic and postsynaptic activity evokes spike timing-dependent long-term potentiation (t-LTP) at primary afferent synapses onto spinal projection neurons. While prior evidence indicates that t-LTP depends upon an elevation in intracellular $\mathrm{Ca}^{2+}$ within projection neurons, the downstream signaling pathways that trigger the observed increase in glutamate release from sensory neurons remain poorly understood. Using in vitro patch-clamp recordings from female mouse lamina I spino-parabrachial neurons, the present study demonstrates a critical role for prostaglandin synthesis in the generation of t-LTP. Bath application of the selective phospholipase $\mathrm{A}_{2}\left(\mathrm{PLA}_{2}\right)$ inhibitor arachidonyl trifluoromethyl ketone $\left(\mathrm{AACOCF}_{3}\right)$ or the cyclooxygenase 2 (Cox-2) inhibitor nimesulide prevented t-LTP at sensory synapses onto spino-parabrachial neurons. Similar results were observed following the block of the EP2 subtype of prostaglandin $\mathrm{E}_{2}\left(\mathrm{PGE}_{2}\right)$ receptor with $\mathrm{PF}$ 04418948. Meanwhile, perfusion with $\mathrm{PGE}_{2}$ or the $\mathrm{EP} 2$ agonist butaprost potentiated the amplitude of monosynaptic primary afferent-evoked EPSCs while decreasing the paired-pulse ratio, suggesting a presynaptic site of action. Cox-2 was constitutively expressed in both spinal microglia and lamina I projection neurons within the superficial dorsal horn (SDH). Suppression of microglial activation with minocycline had no effect on the production of t-LTP, suggesting the possibility that prostaglandins produced within projection neurons could contribute to an enhanced probability of glutamate release at primary afferent synapses. Collectively, the results suggest that the amplification of ascending nociceptive transmission by the spinal SDH network is governed by $\mathrm{PLA}_{2}-\mathrm{Cox}-2-\mathrm{PGE}_{2}$ signaling.

Key words: dorsal horn; LTP; nociception; pain; spinal cord; synapse

Significance Statement

Long-term potentiation (LTP) of primary afferent synapses contributes to the sensitization of spinal nociceptive circuits and has been linked to greater pain sensation in humans. Prior work has implicated elevated glutamate release in the generation of spike timing-dependent LTP (t-LTP) at sensory synapses onto ascending spinal projection neurons, but the underlying mechanisms remain unknown. Here we provide evidence that the activation of EP2 prostaglandin receptors by prostaglandin $\mathrm{E}_{2}$, occurring downstream of phospholipase $A_{2}$ and cyclooxygenase 2 activation, mediates t-LTP at these synapses via changes in presynaptic function. This suggests that prostaglandins can increase the flow of nociceptive information from the spinal cord to the brain independently of their known ability to suppress synaptic inhibition within the dorsal horn.

\section{Introduction}

Synaptic long-term potentiation (LTP) within the superficial dorsal horn $(\mathrm{SDH})$ of the spinal cord has been proposed as an

\footnotetext{
Received July 31, 2017; revised June 8, 2018; accepted June 11, 2018.

Author contributions: J.L., E.S., and M.L.B. designed research; J.L. and E.S. performed research; J.L., E.S., and M.L.B. analyzed data; J.L., E.S., and M.L.B. wrote the paper.

The authors declare no competing financial interests.

This work was supported by the National Institutes of Health (NS080889 to M.L.B.).

Correspondence should be addressed to Dr. Mark L. Baccei, Pain Research Center, Department of Anesthesiology, University of Cincinnati Medical Center, 231 Albert Sabin Way, Cincinnati, OH 45267. E-mail: mark.baccei@uc.edu.
}

important mechanism contributing to the amplification of nociceptive signaling under pathological conditions (Randić et al., 1993; Ikeda et al., 2003; Ruscheweyh et al., 2011). Tetanic electrical stimulation protocols that evoke LTP in the rodent spinal cord in vitro (Svendsen et al., 1997; Ikeda et al., 2006) can exacerbate the severity of pain sensation in humans (Klein et al., 2004; Pfau et al., 2011). Furthermore, pharmacological interventions that prevent LTP in vitro reduce secondary hyperalgesia in humans (Chizh et al., 2007; Klein et al., 2007; Wang et al., 2008; Ruscheweyh 
et al., 2011). Importantly, in vivo extracellular recordings have demonstrated that LTP in the dorsal horn can also be evoked by injury (Sandkühler and Liu, 1998; Zhang et al., 2004). This highlights the critical importance of obtaining a detailed understanding of the molecular underpinnings of synaptic plasticity within the spinal nociceptive network.

Our recent studies ( $\mathrm{Li}$ and Baccei, 2016) demonstrated that precisely correlated activation of sensory afferents and lamina I projection neurons, even at a low frequency, can evoke a form of LTP referred to as spike timing-dependent LTP ( $\mathrm{t}$-LTP; Dan and Poo, 2004; Larsen et al., 2010). This increase in synaptic efficacy, which is seen across multiple classes of primary afferents, reflects an elevation in the probability of glutamate release from the presynaptic terminals of sensory neurons that is blocked by chelation of intracellular calcium $\left(\mathrm{Ca}^{2+}\right)$ within the projection neuron $(\mathrm{Li}$ and Baccei, 2016). This suggests that $\mathrm{Ca}^{2+}$ influx into the projection neuron triggers the release of a retrograde messenger, which acts at the level of the primary afferent to generate t-LTP. Unfortunately, little is known about the potential signaling pathways occurring downstream of this $\mathrm{Ca}^{2+}$ influx that regulate t-LTP at these key synapses within the ascending pain pathway.

Prostaglandin $\mathrm{E}_{2}\left(\mathrm{PGE}_{2}\right)$ synthesis can be triggered by elevations in postsynaptic $\mathrm{Ca}^{2+}$ within $\mathrm{CNS}$ neurons via the activation of phospholipase $\mathrm{A}_{2}\left(\mathrm{PLA}_{2}\right)$ and cyclooxygenase-2 (Cox-2; Yamagata et al., 1993; Chen et al., 2002; Yagami et al., 2016). Cox-2 is known to be significantly upregulated in the spinal dorsal horn after injury (Beiche et al., 1996; Ichitani et al., 1997). However, evidence also points to its constitutive expression within both spinal neurons and glia under naive conditions (Ghilardi et al., 2004). While evidence has demonstrated the ability of $\mathrm{PGE}_{2}$ to dampen glycinergic synaptic inhibition in the SDH (Ahmadi et al., 2002) and increase pain hypersensitivity (Harvey et al., 2004; Reinold et al., 2005), the degree to which prostaglandin signaling governs the activity-dependent plasticity of primary afferent synapses within spinal nociceptive circuits remains incompletely understood.

Therefore the present study tests the hypothesis that spinal prostaglandin signaling is critical to the generation of spike timing-dependent LTP (t-LTP) at primary afferent synapses onto adult lamina I projection neurons. The results clearly demonstrate that $\mathrm{PGE}_{2}$ can elevate glutamate release from primary afferent terminals in the SDH via activation of the EP2 subtype of prostaglandin receptor, and that $\mathrm{PGE}_{2}$ synthesis by the canonical $\mathrm{PLA}_{2}-\mathrm{Cox}-2$ pathway is essential for the generation of t-LTP at sensory synapses onto spino-parabrachial neurons. This represents a novel potential mechanism by which peripheral nerve or tissue damage could directly increase the gain of ascending nociceptive transmission through the spinal pain network via elevations in Cox-2 expression or its downstream effectors.

\section{Materials and Methods}

All experiments adhered to animal welfare guidelines established by the University of Cincinnati Institutional Animal Care and Use Committee.

Retrograde labeling of spino-parabrachial neurons. Adult (17-24 g; 8-11 weeks) female mice [FVB-TgN(GadGFP)45704Swn, stock \#003718; or FVB/NJ, stock \#001800; Jackson Labs] were anesthetized with a mixture of ketamine $(90 \mathrm{mg} / \mathrm{kg})$ and xylazine $(10 \mathrm{mg} / \mathrm{kg})$, given via intraperitoneal injection, and secured in a stereotaxic apparatus. A single injection of 1,1-dilinoleyl-3,3,3,3-tetramethylindocarbocyaninine 4-chlorobenzenesulfonate (FAST DiI) oil $(100-150 \mathrm{nl} ; 2.5 \mathrm{mg} / \mathrm{ml})$ or cholera toxin subunit B (CTB; 75 nl; 5 mg/ml, \#C990; Sigma-Aldrich) was administered into the parabrachial nucleus using a Hamilton microsyringe (62RN; $2.5 \mu$ l volume) equipped with a 28 gauge removable needle. Based on an atlas by Paxinos and Franklin (2012), the following stereo- taxic coordinates were used (relative to bregma): $4.8-5.0 \mathrm{~mm}$ caudal, $1.2-1.4 \mathrm{~mm}$ lateral, and $4.2-4.5 \mathrm{~mm}$ ventral.

In vitro spinal cord slice preparation. At 3-7 d after injection of DiI into the parabrachial nucleus, mice were deeply anesthetized with sodium pentobarbital $(60 \mathrm{mg} / \mathrm{kg})$ and perfused with ice-cold dissection solution consisting of the following (in mM): 250 sucrose, $2.5 \mathrm{KCl}, 25 \mathrm{NaHCO}_{3}$, $1.0 \mathrm{NaH}_{2} \mathrm{PO}_{4}, 6 \mathrm{MgCl}_{2}, 0.5 \mathrm{CaCl}_{2}$, and 25 glucose continuously bubbled with $95 \% \mathrm{O}_{2} / 5 \% \mathrm{CO}_{2}$. The lumbar spinal cord was isolated and immersed in low-melting-point agarose $\left(3 \%\right.$ in above solution) at $37^{\circ} \mathrm{C}$, which was then cooled on ice. Parasagittal slices $(350-400 \mu \mathrm{m})$ with the L3-L4 dorsal roots attached (length, $7-10 \mathrm{~mm}$ ) were cut using a vibrating microtome (7000smz-2, Campden Instruments). Slices were incubated for 15-20 min in a recovery solution containing the following (in $\mathrm{mM}$ ): 92 $\mathrm{N}$-methyl-D-glutamine, $2.5 \mathrm{KCl}, 1.2 \mathrm{NaH}_{2} \mathrm{PO}_{4}, 30 \mathrm{NaHCO}_{3}, 20 \mathrm{HEPES}$, 25 glucose, $5 \mathrm{Na}$ ascorbate, 2 thiourea, $3 \mathrm{Na}$ pyruvate, $10 \mathrm{MgSO}_{4}$, and 0.5 $\mathrm{CaCl}_{2}$ (Ting et al., 2014). Then slices were allowed to recover further for $\geq 1 \mathrm{~h}$ at room temperature in an oxygenated artificial CSF (aCSF) solution containing the following (in mM): $125 \mathrm{NaCl}, 2.5 \mathrm{KCl}, 25 \mathrm{NaHCO}_{3}$, $1.0 \mathrm{NaH}_{2} \mathrm{PO}_{4}, 1.0 \mathrm{MgCl}_{2}, 2.0 \mathrm{CaCl}_{2}$, and 25 glucose.

Patch-clamp recordings from identified lamina I spino-parabrachial neurons. After recovery, slices were transferred to a submersion-type recording chamber (RC-22, Warner Instruments) and mounted on the stage of an upright microscope (BX51WI, Olympus). Slices were then perfused at room temperature with oxygenated aCSF at a rate of 3-6 $\mathrm{ml} / \mathrm{min}$.

Patch electrodes were constructed from thin-walled single-filamented borosilicate glass (1.5 mm outer diameter; World Precision Instruments) using a microelectrode puller (P-97, Sutter Instruments). Pipette resistances ranged from 4 to $6 \mathrm{M} \Omega$ and seal resistances were $>1 \mathrm{G} \Omega$. Patch electrodes were filled with an intracellular solution containing the following (in $\mathrm{mm}$ ): $130 \mathrm{~K}$-gluconate, $10 \mathrm{KCl}, 10 \mathrm{HEPES}, 10 \mathrm{Na}$ phosphocreatine, 4 MgATP, and 0.3 $\mathrm{Na}_{2}$-GTP, pH 7.2 (295-300 mOsm).

Whole-cell patch-clamp recordings were obtained from DiI-labeled lamina I neurons using a Multiclamp 700B amplifier (Molecular Devices) at a holding potential of $-70 \mathrm{mV}$. EPSCs were evoked via electrical stimulation $(0-1 \mathrm{~mA}, 100 \mu$ s duration) delivered via a suction electrode connected to a constant current stimulator (Master-8, A.M.P.I.). EPSC threshold was defined as the current intensity that evoked a measurable EPSC in $\geq 50 \%$ of the trials. Monosynaptic EPSCs were defined by a stable onset latency ( $\leq 2 \mathrm{~ms}$ variation) and absence of failures in response to repetitive stimulation ( $\mathrm{Li}$ et al., 2015). A combination of stimulus threshold and onset latency of the monosynaptic EPSC was used to classify the subtype of primary afferent input (i.e., presumed $\mathrm{A} \beta$ fiber, $\mathrm{A} \delta$ fiber, high-threshold $\mathrm{C}$ fiber, or low-threshold $\mathrm{C}$ fiber) as described in detail previously (Li et al., 2015). To evaluate the effects of $\mathrm{PGE}_{2}$ signaling on the probability of glutamate release at primary afferent synapses, paired electrical stimuli were applied to the dorsal root at an interstimulus interval of 50-250 ms both before and after bath application of $\mathrm{PGE}_{2}$ $(10 \mu \mathrm{M})$ or the selective EP2 receptor agonist butaprost (5-10 $\mu \mathrm{M})$, and the paired-pulse ratio (PPR) was calculated as follows: mean EPSC2/ mean EPSC1. The effects of EP3 receptor activation on afferent-evoked EPSCs were examined via the bath application of sulprostone $(5 \mu \mathrm{M})$. In some experiments, miniature EPSCs (mEPSCs) were recorded from a holding potential of $-70 \mathrm{mV}$ in the presence of $500 \mathrm{~nm}$ TTX.

Induction of $t$-LTP in spinal projection neurons. Monosynaptic EPSCs were evoked in projection neurons from a holding potential of $-70 \mathrm{mV}$ by stimulation of the attached dorsal root (every $15 \mathrm{~s}$ at an intensity of $1-1.2 \times$ threshold). Isolated monosynaptic EPSCs could be conclusively attributed to a particular class of primary afferent in 69 sampled projection neurons, with $\sim 26 \%$ (i.e., 18 of 69 ) of the EPSCs mediated by high-threshold C fibers, $25 \%$ mediated by A $\delta$ fibers, $27 \%$ mediated by low-threshold $\mathrm{C}$ fibers, and $22 \%$ mediated by presumed $\mathrm{A} \beta$ fibers. Following the verification of a stable baseline EPSC amplitude for $\geq 5 \mathrm{~min}$, the same primary afferent stimulus was paired with a postsynaptic action potential evoked by direct intracellular current injection $(300-800 \mathrm{pA}$, $5 \mathrm{~ms})$ at an interval ( $\Delta t=-10 \mathrm{~ms})$ that we previously demonstrated to evoke maximal t-LTP in spino-parabrachial neurons (Li and Baccei, 2016). After administration of the pairing protocol (30 pairs of stimuli at $0.2 \mathrm{~Hz}$ ), projection neurons were again voltage-clamped at $-70 \mathrm{mV}$ and 
the primary afferent-evoked EPSCs recorded for $\geq 25$ min to calculate a mean normalized change in EPSC amplitude (percentage of baseline). As reported previously ( $\mathrm{Li}$ and Baccei, 2016), we observed t-LTP at synapses mediated by all classes of primary afferents, but lacked sufficient sample sizes to rigorously examine the degree to which the properties of t-LTP vary depending on the functional subtype of the DRG neuron. In some cases, the above experiments were conducted in the presence of pharmacological inhibitors of $\mathrm{PLA}_{2}$ (AA$\mathrm{COCF}_{3} ; 10 \mu \mathrm{M}$ ), Cox-2 (nimesulide; $10 \mu \mathrm{M}$ ), or microglial activity (minocycline; $10 \mu \mathrm{M}$ ), or in the presence of selective antagonists to the EP2 subtype of prostaglandin receptors (PF 04418948; $50 \mu \mathrm{M})$. Drugs were bath-applied starting 15-20 min before the initiation of the t-LTP induction protocol and were present throughout the remainder of the experiment.

Membrane voltages were adjusted for liquid junction potentials calculated using JPCalc software (P. Barry, University of New South Wales, Sydney, Australia; modified for Molecular Devices). Currents were filtered at $4-6 \mathrm{kHz}$ through a $-3 \mathrm{~dB}$, four-pole low-pass Bessel filter, digitally sampled at $20 \mathrm{kHz}$, and stored on a personal computer (International Computer Technology) using a commercially available data acquisition system (Digidata 1440A with pClamp 10.4 software, Molecular Devices).

Immunohistochemical localization of Cox-2 in the spinal SDH. Eightweek-old wild-type FVB/NJ mice were killed via overdose of sodium pentobarbital and transcardially perfused with $4 \%$ paraformaldehyde (PFA) in $0.1 \mathrm{M}$ phosphate buffer (PB). Brains and lumbar spinal cords were dissected out, then postfixed for an additional $4 \mathrm{~h}$ in $4 \% \mathrm{PFA}$. Tissue was cryoprotected overnight in a solution of $30 \%$ sucrose in $0.1 \mathrm{M} \mathrm{PB}$, and then sectioned at $40 \mu \mathrm{m}$ for free-floating immunohistochemical processing. Sections were washed three times in $0.01 \mathrm{M}$ PBS, then permeabilized for $1 \mathrm{~h}$ with $0.3 \%$ Triton X-100 in PBS (PBS-Tx). Sections were then blocked for $2 \mathrm{~h}$ in 10\% normal donkey serum (Sigma-Aldrich, catalog \#D9663) in PBS-Tx. Primary antibodies (goat anti-CTB: 1:3000, List Biological Laboratories, catalog \#703, RRID:AB_10013220; rabbit antiCox2: 1:1000; Abcam, catalog \#ab15191, RRID:AB_2085144; goat anti-Ibal: 1:1000, Novus Biologicals, catalog \#NB100-1028, RRID: AB_521594) were diluted in 3\% normal donkey serum in PBS-Tx. Brain sections were stained with anti-CTB only, to verify accuracy of stereotaxic injection, while spinal cord sections were incubated simultaneously with anti-CTB and anti-Cox-2, or with anti-Cox-2 and anti-Ibal. Sections were incubated with primary antibodies overnight at $4^{\circ} \mathrm{C}$, then washed three times with PBS-Tx. Secondary antibodies (AlexaFluor 594 donkey anti-goat: 1:500, Thermo Fisher Scientific, catalog \#A11058, RRID:AB_2534105; AlexaFluor 488 donkey anti-rabbit: 1:500, Thermo Fisher Scientific, catalog \#21206, RRID:AB_2535792) were diluted in 3\% normal donkey serum in PBS-Tx and incubated for $1 \mathrm{~h}$ at room temperature. Finally, sections were washed three times with PBS then mounted on ColorFrost charged slides (Thermo Fisher Scientific, catalog \#12-55019) and coverslipped with VectaShield mounting medium (Vector Laboratories, catalog \#H-1000, RRID:AB_2336789).

Imaging. Images of immunostained tissue sections were captured on an Olympus BX63 fluorescent microscope using a $20 \times$ objective. Multichannel $z$-stack images were obtained with a $z$-separation of $1.0 \mu \mathrm{m}$ per slice. Each optical slice was examined for potential colocalization between CTB and Cox-2, or between Cox-2 and Ibal immunoreactivity. $Z$-stack images were projected as an extended focus image using CellSens acquisition and processing software (Olympus, RRID:SCR_014551). Figures were assembled using Photoshop CS5 (Adobe, RRID: SCR 014199).

Experimental design and statistical analysis. Given our earlier work suggesting that the effects of neonatal surgical injury on synaptic transmission within the developing SDH are more pronounced in females $(\mathrm{Li}$ and Baccei, 2011), our more recent studies have relied on female mice to identify the prolonged consequences of early-life incision for t-LTP in lamina I projection neurons ( $\mathrm{Li}$ and Baccei, 2016). Therefore, female mice were used for all studies described here to enhance the validity of comparisons with previous findings. However, it should be noted that the stage of estrus was not examined during the present study. For the experiment illustrated in Figure 2, data (DMSO control: $n=5$ cells from 5 mice; $\mathrm{AACOCF}_{3}: n=9$ cells from 6 mice; PF 04418948: $n=9$ cells from 8 mice) were analyzed using one-way ANOVA with drug as a factor with Dunnett's post-test for multiple comparisons (Prism 5.0 software, GraphPad Software). For the experiments involving the application of $\mathrm{PGE}_{2}$ (see Figs. 3, 4), 17 cells were recorded from seven mice. The effects of $\mathrm{PGE}_{2}$ on EPSC amplitude were analyzed with the Wilcoxon signedrank test and PPRs were analyzed using repeated measures two-way ANOVA (with Bonferroni post-tests for multiple comparisons) with drug ( $\mathrm{PGE}_{2}$ or vehicle) and interstimulus interval as factors. Meanwhile, mEPSC results were analyzed with the Wilcoxon signed-rank test since these data failed the D'Agostino and Pearson normality test. Regarding the application of butaprost to projection neurons, 13 cells were sampled from nine mice in the studies depicted in Figure $5 A-D$ (involving the prolonged application of butaprost) and four cells from two mice for the experiments involving short-duration agonist application (see Fig. $5 E, F)$. Meanwhile, the effects of the $\mathrm{EP} 3$ receptor agonist sulprostone on afferent-evoked EPSCs (see Fig. 5G,H) were examined in five cells from four mice. The results of the aforementioned experiments were analyzed in a similar manner as described above for the experiments involving $\mathrm{PGE}_{2}$ unless otherwise indicated. The effects of the Cox-2 inhibitor nimesulide ( $n=6$ cells from 4 mice) versus vehicle ( $n=4$ cells from 4 mice) on t-LTP (see Fig. 6) were compared using the Mann-Whitney test. Finally, the investigation into the effects of fractalkine on mEPSCs (see Fig. 8C) used 12 cells from five mice, while the application of fractalkine in the presence of minocycline (see Fig. $8 D$ ) involved sampling seven cells from two mice. In both instances, data were analyzed using the Wilcoxon signed-rank test as data failed the D'Agostino and Pearson normality test. For the remainder of the manuscript, $n$ refers to the number of neurons sampled in a given group. Data are expressed as means \pm SEM.

\section{Results}

PLA $_{2}$ signaling drives t-LTP at sensory synapses onto projection neurons via activation of EP2 receptors

Our prior work showed that postsynaptic $\mathrm{Ca}^{2+}$ influx is essential for the generation of t-LTP at primary afferent synapses onto lamina I spino-parabrachial neurons ( $\mathrm{Li}$ and Baccei, 2016). Since the activation of $\mathrm{PLA}_{2}$ by intracellular $\mathrm{Ca}^{2+}$ is known to regulate glutamatergic synaptic efficacy in other regions of the CNS (Massicotte et al., 1990; Su et al., 2013), we first examined the potential role of $\mathrm{PLA}_{2}$ in the generation of t-LTP at sensory synapses onto mouse spino-parabrachial neurons. As we demonstrated previously, highly correlated activity in which the presynaptic input preceded postsynaptic action potential discharge by a brief inter- 
A

$$
+\mathrm{AACOCF}_{3}
$$

(PLA ${ }_{2}$ inhibitor)

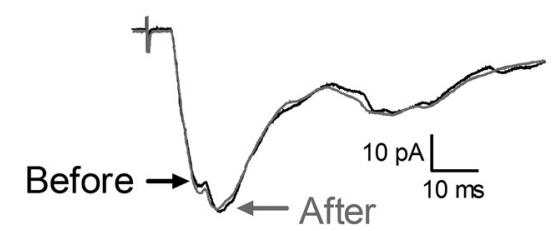

B

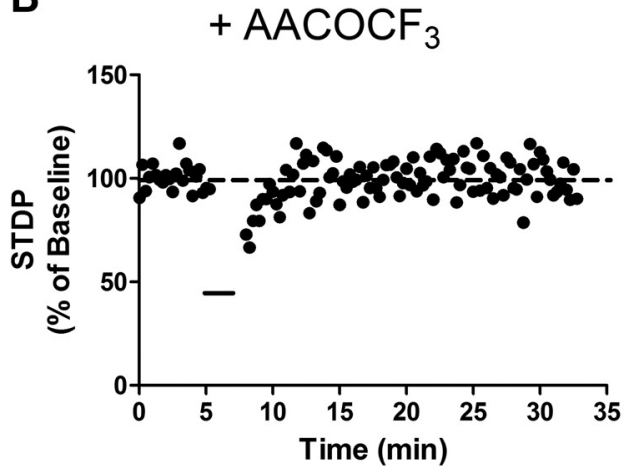

C

+ PF 04418948

(EP2 antagonist)

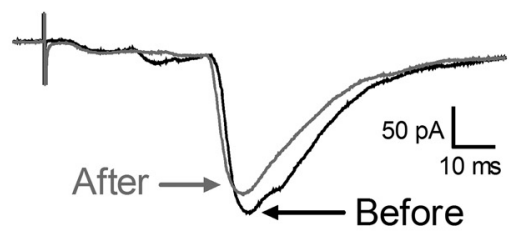

D

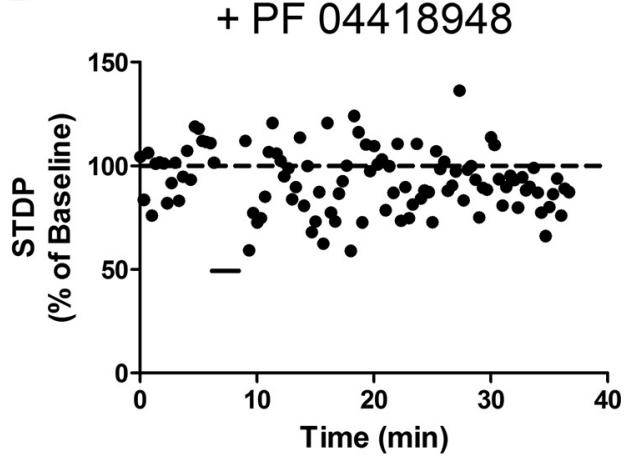

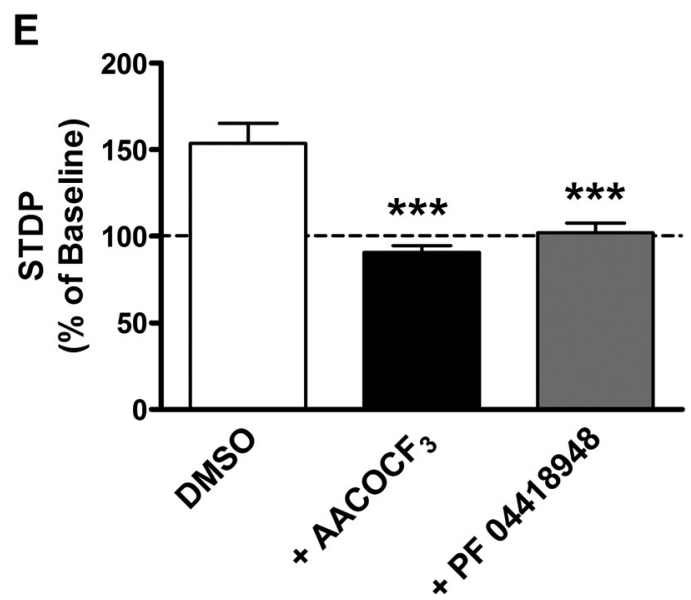

Figure 2. T-LTP at sensory synapses onto projection neurons requires activation of PLA 2 and EP2 receptor signaling. $A$, Representative EPSCs showing that the STDP protocol failed to alter EPSC amplitude in the presence of the PLA inhibitor AACOCF $3(10 \mu \mathrm{M})$. $\boldsymbol{B}$, Representative plot of STDP (expressed as a percentage of baseline EPSC amplitude before pairing, where $100 \%$ indicates no change in synaptic efficacy) versus time, showing a lack of t-LTP following the administration of the pairing protocol (black bar) in the presence of AACOCF 3 . C, D, The pairing protocol also had no effect on EPSC amplitude when administered in the presence of the EP2 receptor antagonist PF $04418948(50 \mu \mathrm{M})$. $E$, Summary of data showing an absence of $\mathrm{t}-\mathrm{LTP}$ in the presence of PLA inhibition or EP2 receptor antagonism ( $n=5-9$ in each group; $p<0.0001$; 1-way ANOVA; *** $p<0.001$ vs DMSO control; Dunnett's post-test).

val (i.e., Pre $\rightarrow$ Post pairings at $\Delta t=-10 \mathrm{~ms}$; Fig. $1 A$ ) consistently evoked t-LTP in lamina I projection neurons (Fig. 1B). However, when the same pairing protocol was administered in the presence of the $\mathrm{PLA}_{2}$ inhibitor $\mathrm{AACOCF}_{3}$, no t-LTP was observed (Fig. $2 A, B$ ). The absence of synaptic potentiation was not explained by intracellular dialysis in the whole-cell recording configuration occurring during the period of $\mathrm{AACOCF}_{3}$ pretreatment (15-20 $\mathrm{min}$ ), as robust t-LTP was observed following the equivalent perfusion with the vehicle solution (DMSO: $n=5$; $\mathrm{AACOCF}_{3}: n=9 ; F_{(2,20)}=22.41 ; p<0.0001$; one-way ANOVA; $p<0.001$; Dunnett's post-test; Fig. 2E).

Given the ability of $\mathrm{PLA}_{2}$ activation to trigger prostaglandin production in the CNS, we next investigated the degree to which spinal prostaglandin receptors modulated spike timing-dependent plasticity (STDP) at sensory synapses onto projection neurons. Although multiple subtypes of receptors for $\mathrm{PGE}_{2}$ can regulate spinal nociceptive processing (Bär et al., 2004), we focused on the EP2 subtype of $\mathrm{PGE}_{2}$ receptor as it has been previously shown to potentiate glutamate release from presynaptic terminals in the brain (Sang et al., 2005). Therefore, the selective EP2 antagonist PF 04418948 was bath applied before (and during) the administration of the pairing protocol that normally evokes t-LTP (Pre $\rightarrow$ Post pairings at $\Delta t=-10 \mathrm{~ms}$ ). The results clearly indicate that EP2 receptor activation is essential for the generation of t-LTP in ascending lamina I spino-parabrachial neurons (Fig. 2C,D), as treatment with PF 04418948 abolished the activity-dependent 
A

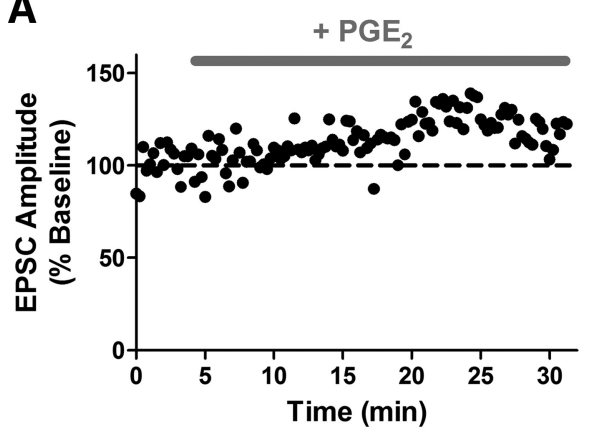

B

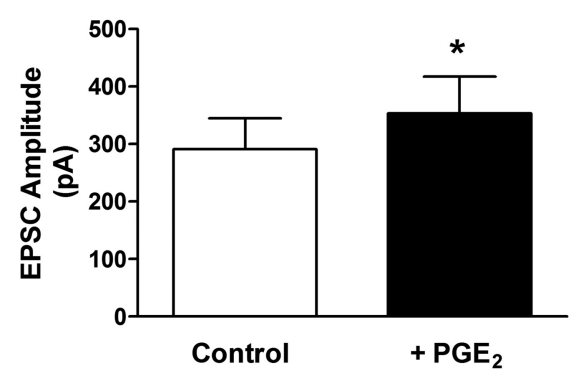

C

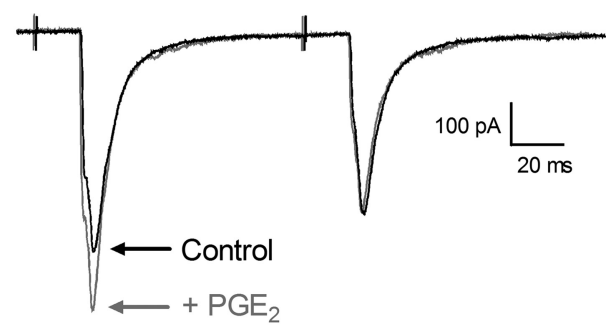

D

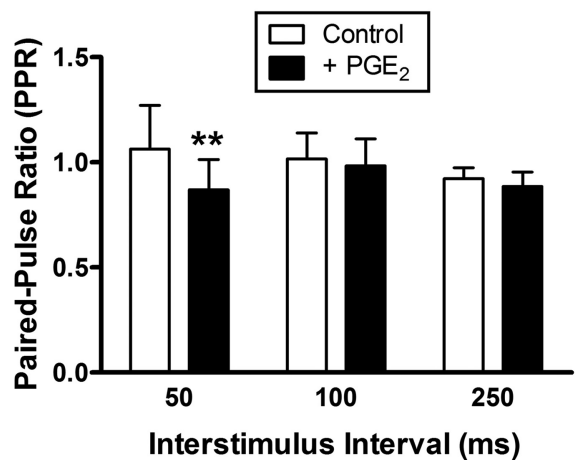

Figure 3. $\mathrm{PGE}_{2}$ potentiates primary afferent-evoked EPSCs in mature lamina I projection neurons via presynaptic mechanisms. $A$, Representative plot of current versus time illustrating a slight increase in EPSC amplitude in response to the bath application of $\mathrm{PGE}_{2}(10 \mu \mathrm{M}) . \boldsymbol{B}, \mathrm{PGE}_{2}$ significantly increased monosynaptic EPSC amplitude in adult projection neurons $\left(n=7 ;{ }^{*} p=0.0156\right.$; Wilcoxon signed-rank test). $\boldsymbol{C}$, Examples of EPSCs evoked by paired stimulation in the absence (black) and presence (gray) of PGE ${ }_{2}$. $\boldsymbol{D}$, The PPR was significantly decreased by $\mathrm{PGE},(n=7 ; p=0.006$; repeated-measures 2-way ANOVA; ${ }^{*} p<0.01$; Bonferroni post-test), suggesting an elevation in the probability of glutamate release from the terminals of sensory afferents.

A Baseline

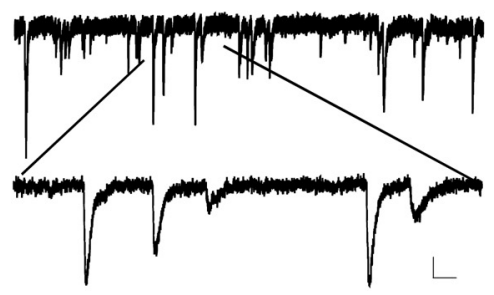

$+\mathrm{PGE}_{2}$

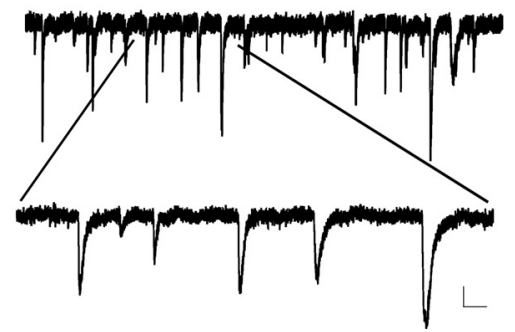

B

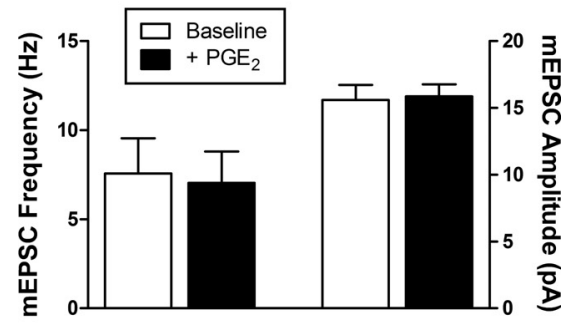

Figure 4. $\mathrm{PGE}_{2}$ does not evoke a widespread elevation in spontaneous glutamate release onto lamina I projection neurons. $A$, Examples of $\mathrm{mEPSCS}$ recorded in the presence of $500 \mathrm{~nm}$ TTX before (left) and after (right) bath application of $10 \mu \mathrm{M} \mathrm{PGE}$. Bottom traces illustrate mEPSCs at an expanded time base. Scale bars, $20 \mathrm{pA}, 50 \mathrm{~ms}$. B, Application of PGE 2 failed to significantly affect the frequency (left; $n=5 ; p=0.813$; Wilcoxon signed-rank test) or amplitude (right; $p=0.625$ ) of mEPSCs recorded in adult spino-parabrachial neurons.

potentiation of primary afferent synapses by the pairing protocol $(n=9 ; p<0.001$ compared with DMSO control; one-way ANOVA with Dunnett's post-test; Fig. 2E).

$\mathrm{PGE}_{2}$ strengthens primary afferent input to spino-parabrachial neurons via presynaptic mechanisms Our previous studies showed that the chelation of intracellular $\mathrm{Ca}^{2+}$ within projection neurons not only blocks the synaptic potentiation, but also prevents the reduction in the PPR of primary afferent-evoked EPSCs, normally produced by the t-LTP pairing protocol (Li and Baccei, 2016). Combined with the above results demonstrating the importance of $\mathrm{PLA}_{2}$ activity and EP2 receptor signaling for the generation of t-LTP, this raises the possibility that $\mathrm{PGE}_{2}$ activation of $\mathrm{EP} 2$ receptors elevates the probability of glutamate release from the terminals of primary afferents and thereby increases the efficacy of sensory synapses onto projection neurons. To provide further support for this working model, we investigated the effects of exogenous $\mathrm{PGE}_{2}$ on primary afferent synaptic inputs to lamina I spino-parabrachial neurons. Bath application of $\mathrm{PGE}_{2}(10 \mu \mathrm{M})$ significantly increased the amplitude of monosynaptic EPSCs in spinal projection neurons following stimulation of the attached dorsal root $(t=4.26 ; n=7 ; p=0.0156$; Wilcoxon signed-rank test; Fig. $3 A, B)$. In addition, $\mathrm{PGE}_{2}$ significantly decreased the PPR of the afferent-evoked EPSCs across the range of interstimulus intervals examined $\left(n=7 ; F_{(1,18)}=9.81 ; p=0.006\right.$; repeated-measures two-way ANOVA; Fig. $3 C, D$ ), suggesting that $\mathrm{PGE}_{2}$ facilitates sensory input to ascending projection neurons via presynaptic mechanisms.

To investigate whether $\mathrm{PGE}_{2}$ evokes a global increase in glutamate release onto ascending projection neurons, we next characterized the effects of bath-applied $\mathrm{PGE}_{2}$ on the frequency and 
A

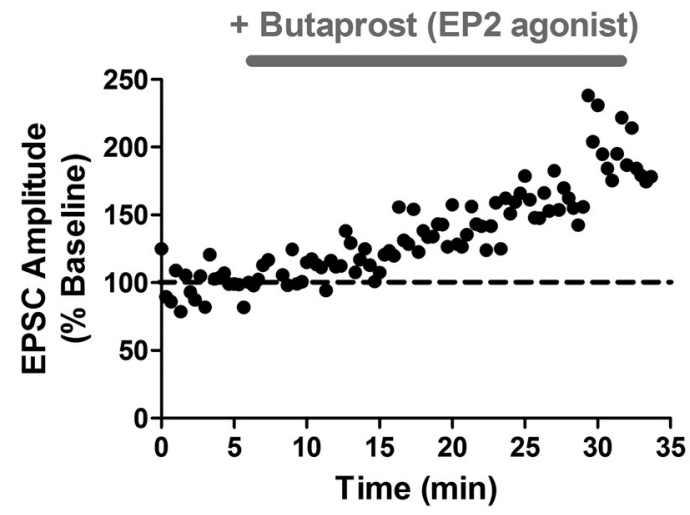

C

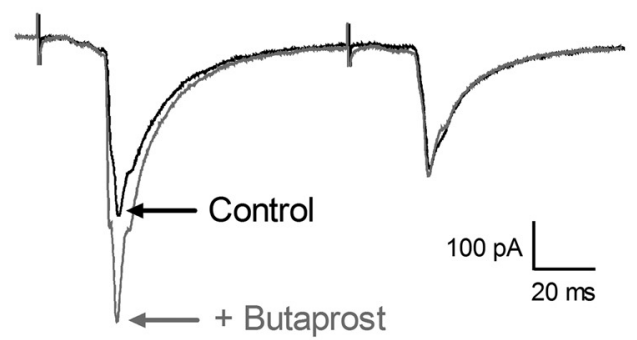

E

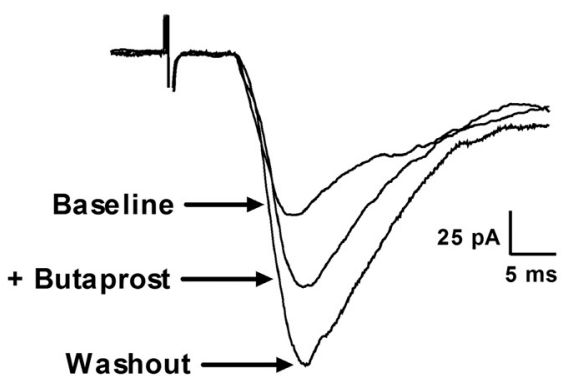

G

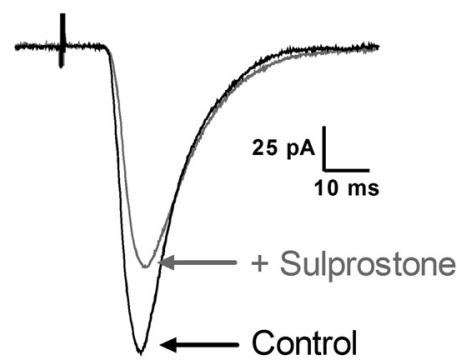

B

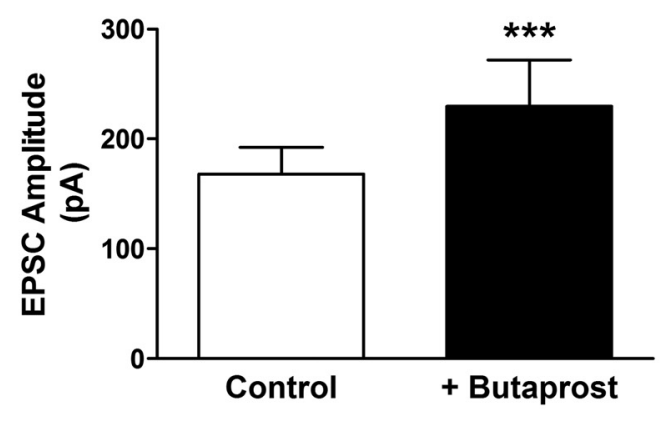

D

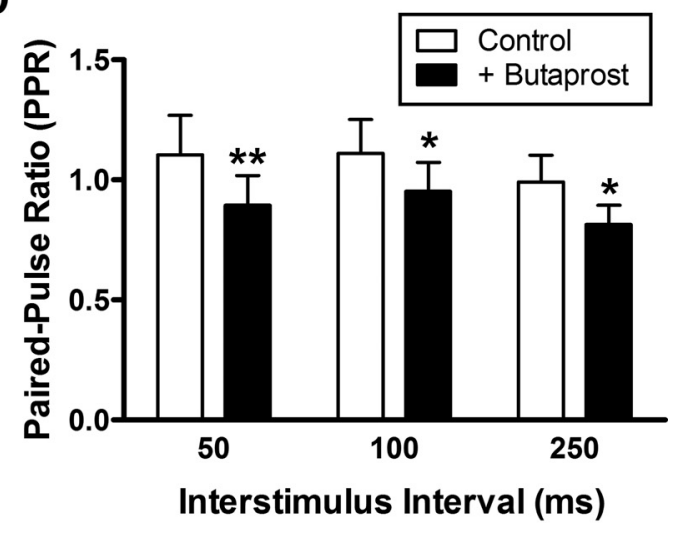

F

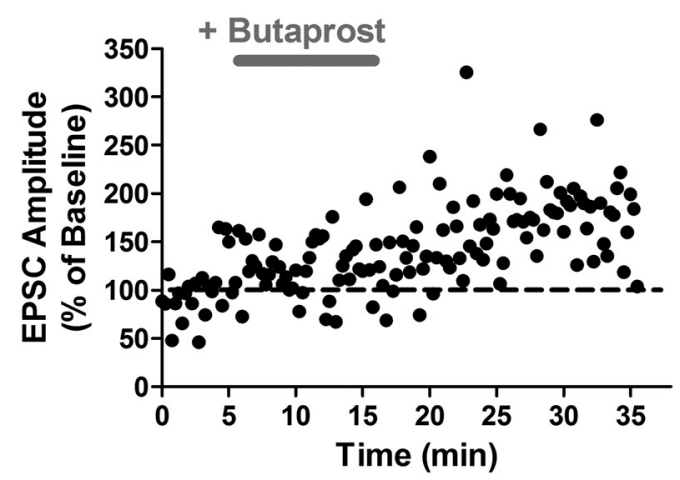

H

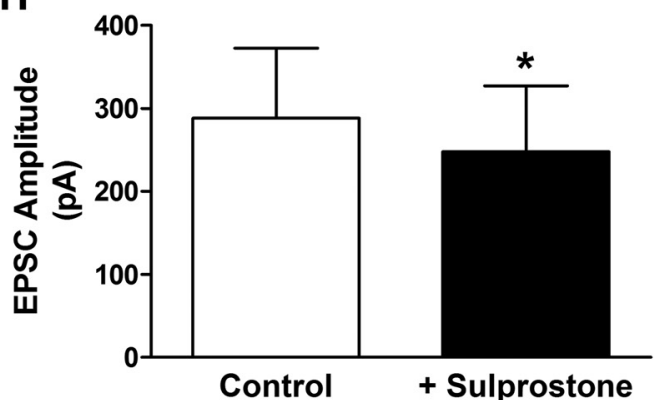

Figure 5. EP2 receptor activation enhances glutamate release at sensory synapses onto adult spino-parabrachial neurons. $A$, Representative plot of current versus time illustrating an increase in the amplitude of primary afferent-evoked EPSCs in response to the bath application of the EP2 receptor agonist butaprost (10 $\mu \mathrm{M})$. B, Butaprost (5-10 $\mu \mathrm{M})$ significantly increased monosynaptic primary afferent-evoked EPSC amplitude in projection neurons $\left(n=13 ;{ }^{* * *} p=0.0005\right.$; Wilcoxon signed-rank test). C, Examples of afferent-evoked EPSCs evoked by paired stimulation in the absence (black) and presence (gray) of butaprost. $\boldsymbol{D}$, The PPR was significantly decreased by EP2 receptor activation $\left(n=13 ; p<0.0001\right.$; repeated-measures 2 -way ANOVA; $p<0.05$; ${ }^{* *} p<0.01$; Bonferroni post-test), indicative of an elevated probability of glutamate release at primary afferent synapses onto mature projection neurons. $\boldsymbol{E}$, Representative traces illustrating monosynaptic, primary afferent-evoked EPSCS at baseline, during the application of the EP2 receptor agonist butaprost, and 20 min after washout with aCSF. F, Plot of EPSC amplitude (Figure legend continues.) 
amplitude of mEPSCs recorded in lamina I spino-parabrachial neurons (Fig. 4A). We observed no significant effect of $\mathrm{PGE}_{2}$ on the frequency $(n=5 ; W=3.0 ; p=0.813$; Wilcoxon signed-rank test; Fig. $4 B$, left) or amplitude ( $W=-5.0 ; p=0.625$; Wilcoxon signed-rank test; Fig. $4 B$, right) of mEPSCs in projection neurons, thus raising the possibility that $\mathrm{PGE}_{2}$ selectively modulates glutamatergic signaling at primary afferent synapses within the dorsal horn.

To determine whether the selective activation of EP2 receptors mimics the effects of $\mathrm{PGE}_{2}$ on primary afferent-mediated glutamatergic transmission to spino-parabrachial neurons, we performed similar experiments using the selective EP2 agonist butaprost (Fig. 5). As seen with $\mathrm{PGE}_{2}$, perfusion of the spinal cord slice with butaprost $(5-10 \mu \mathrm{M})$ enhanced the amplitude of afferent-evoked monosynaptic EPSCs $(n=13 ; W=-89 ; p=$ 0.0005; Wilcoxon signed-rank test; Fig. $5 A, B$ ). Meanwhile, the PPR was significantly reduced by the EP2 agonist at interstimulus intervals ranging from 50 to $250 \mathrm{~ms}\left(n=13 ; F_{(1,36)}=26.97 ; p<\right.$ 0.0001 ; repeated-measures two-way ANOVA; Fig. $5 C, D)$. This is consistent with the notion that $\mathrm{EP} 2$ receptors regulate the efficacy of sensory synapses onto lamina I projection neurons. Finally, as would be predicted if EP2 receptor activation contributes to the generation of t-LTP at these synapses, the enhancement in EPSC amplitude persisted beyond the presence of the agonist itself (Fig. $5 E, F)$, as the mean EPSC amplitude after $20 \mathrm{~min}$ of washout with aCSF was slightly greater $(149.6 \pm 20.3 \%$ of baseline $)$ than that observed during the perfusion with butaprost $(133.9 \pm 16.3 \%$ of baseline; $n=4)$.

While EP2 receptors have been shown to sensitize nociceptive circuits via stimulation of $\mathrm{G}_{\mathrm{s}}$-coupled signaling pathways and can drive inflammatory hyperalgesia (Reinold et al., 2005), EP3 receptors are thought to predominantly signal via $G_{i}$ to prevent the sensitization of sensory neurons by $\mathrm{PGE}_{2}$ and can evoke analgesia under pathological conditions (Natura et al., 2013). As a result, we hypothesized that the activation of EP3 receptors would fail to potentiate primary afferent synapses onto spinal projection neurons. To test this hypothesis, we next examined the effects of the EP3 receptor agonist sulprostone on the amplitude of afferent-evoked EPSCs in spino-parabrachial neurons. The data demonstrate that EP3 receptor activation leads to a slight, but significant, depression of EPSC amplitude $(n=5 ; t=4.177 ; p=$ 0.014; paired $t$ test; Fig. $5 G, H$ ), suggesting that the balance of EP2 versus EP3 receptor signaling could have a strong influence on the gain of sensory input to spinal projection neurons.

\section{Role of Cox-2 in the production of t-LTP in ascending spinal projection neurons}

Given the known importance of Cox-2 for the production of prostaglandins (Yamagata et al., 1993; Chen et al., 2002), the above data suggest the possibility that endogenous Cox-2 activity is required for the generation of t-LTP at primary afferent synapses onto lamina I projection neurons. To elucidate the potential role of Cox-2 in this plasticity, the t-LTP pairing protocol was administered following the bath administration of the selective Cox-2 inhibitor nimesulide (Fig. 6). Although a modest increase

\section{$\leftarrow$}

(Figure legend continued.) versus time demonstrating that the increase in synaptic efficacy evoked by EP2 receptor activation outlasts the presence of the agonist (gray bar). G, Examples of afferent-evoked EPSCS before (Control) and after bath application of the EP3 receptor agonist sulprostone. $\boldsymbol{H}$, Sulprostone significantly decreased the amplitude of primary afferent-evoked EPSCs in lamina I projection neurons $\left(n=5 ; t=4.177 ;{ }^{*} p=0.014\right.$; paired $t$ test). in EPSC amplitude could be observed after the pairing protocol was administered in the presence of nimesulide (Fig. $6 A, B$ ), the degree of potentiation was significantly reduced compared with the vehicle (i.e., DMSO) control group ( $n=4-6$ in each group; $U=0 ; p=0.009$; Mann-Whitney test; Fig. 6C).

\section{Constitutive expression of Cox-2 within spinal nociceptive circuits}

To determine the degree to which Cox-2 may be expressed within spinal projection neurons in the mouse SDH, CTB was injected into the parabrachial nucleus to retrogradely label ascending projection neurons. The spinal cord was subsequently processed for immunohistochemistry using a primary antibody raised against Cox-2 (see Materials and Methods). CTB-labeled spino-parabrachial neurons located in lamina I (Fig. $7 A, D$ ) exhibited clear immunoreactivity for Cox-2 (Fig. $7 B, C, E, F$ ) under naive conditions. Nonetheless, the strongest immunoreactivity for Cox-2 was observed within microglia in the dorsal horn, as evidenced by extensive colocalization with the microglial marker Ibal (Fig. $7 G-I$ ). These results support prior findings of constitutive Cox-2 expression within multiple cell types across the SDH (Ghilardi et al., 2004), and raise the possibility that Cox-2 activation in the projection neurons themselves, and/or spinal microglia, is involved in the generation of t-LTP at primary afferent synapses onto spino-parabrachial neurons.

\section{t-LTP at afferent synapses onto spino-parabrachial neurons does not require the activation of microglia in the spinal dorsal horn}

Since the activation of spinal microglia is known to regulate the strength of primary afferent synapses in the spinal SDH (Clark et al., 2015), we investigated a potential role for microglia in the generation of t-LTP in ascending projection neurons. Notably, the prior application of the microglial inhibitor minocycline failed to block t-LTP in this population (Fig. $8 A, B$ ), as the amplitude of the primary afferent-evoked EPSCs averaged $148.7 \pm$ $8.2 \%$ of baseline $(n=7)$ following the administration of the t-LTP pairing protocol. As a positive control to ensure the efficacy of minocycline under our experimental conditions, we examined its ability to prevent the increase in glutamatergic transmission evoked by the bath application of the selective CX3CR1 agonist fractalkine $(100 \mathrm{ng} / \mathrm{ml})$. As reported previously (Clark et al., 2015), fractalkine significantly elevated the frequency of mEPSCs $(W=-21 ; p=0.031 ; n=6$; Wilcoxon signed-rank test; Fig. $8 C$, left) without altering mEPSC amplitude ( $W=7 ; p=0.562$; Fig. $8 C$, right). Prior bath application of minocycline prevented the subsequent elevation in mEPSC frequency by fractalkine $(W=-1 ; p=1.0 ; n=6$; Wilcoxon signedrank test; Fig. $8 D$, left). As a result, the observed persistence of t-LTP in the presence of minocycline argues against an essential role for activated spinal microglia in the presently used model of spike timing-dependent synaptic plasticity.

\section{Discussion}

Spinal projection neurons convey noxious sensory information to multiple pain-processing circuits in the brain, including the parabrachial nucleus, the periaqueductal gray, the caudal ventrolateral medulla, and the thalamus (Todd, 2010). Given the considerable evidence that these ascending pathways are essential for pain sensation in both humans (Spiller and Martin, 1912; Friehs et al., 1995) and rodents (Mantyh et al., 1997; Nichols et al., 1999), it is imperative to gain a complete understanding of the factors that regulate the strength of direct sensory inputs to spinal 
A

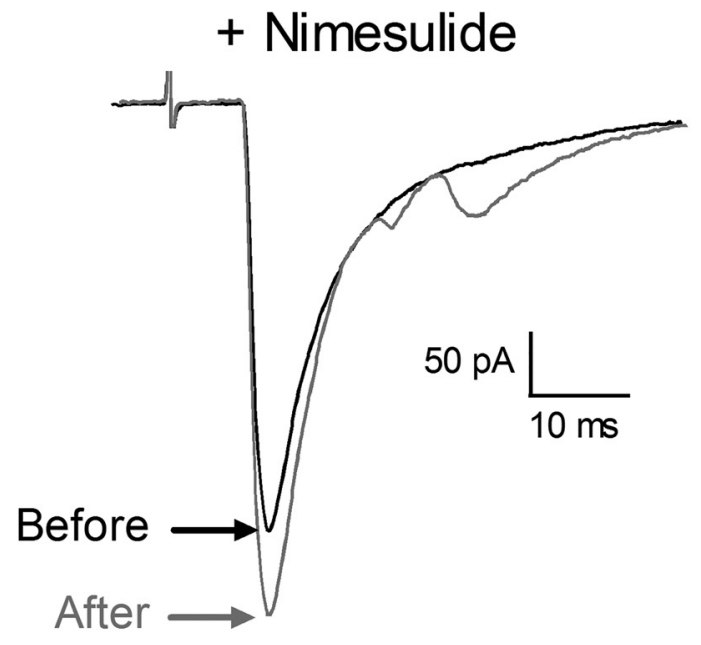

B

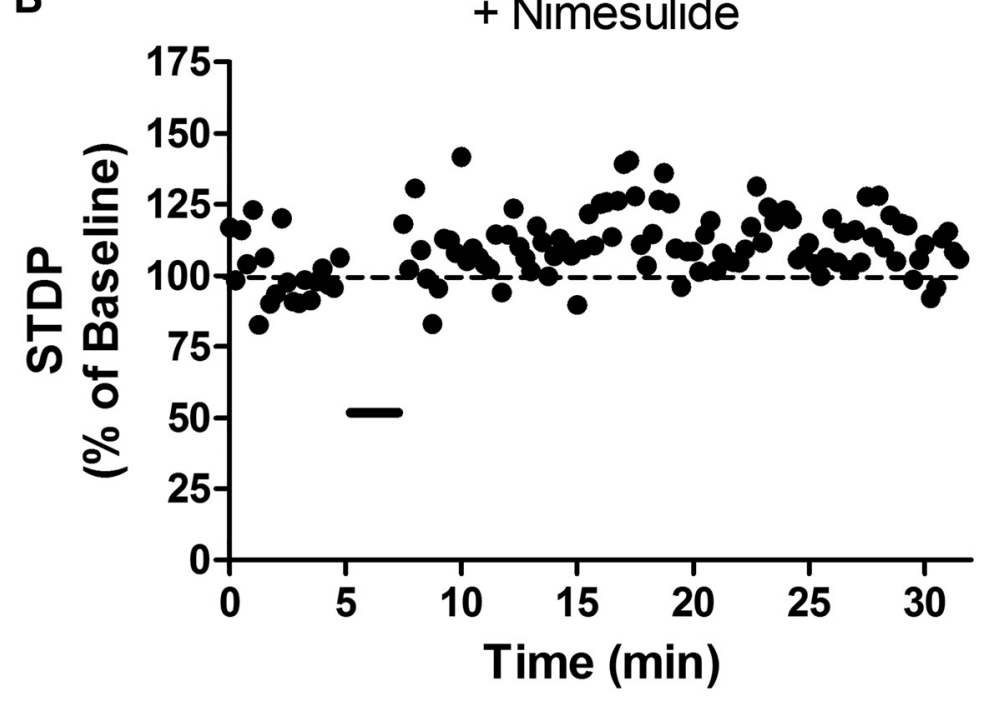

C

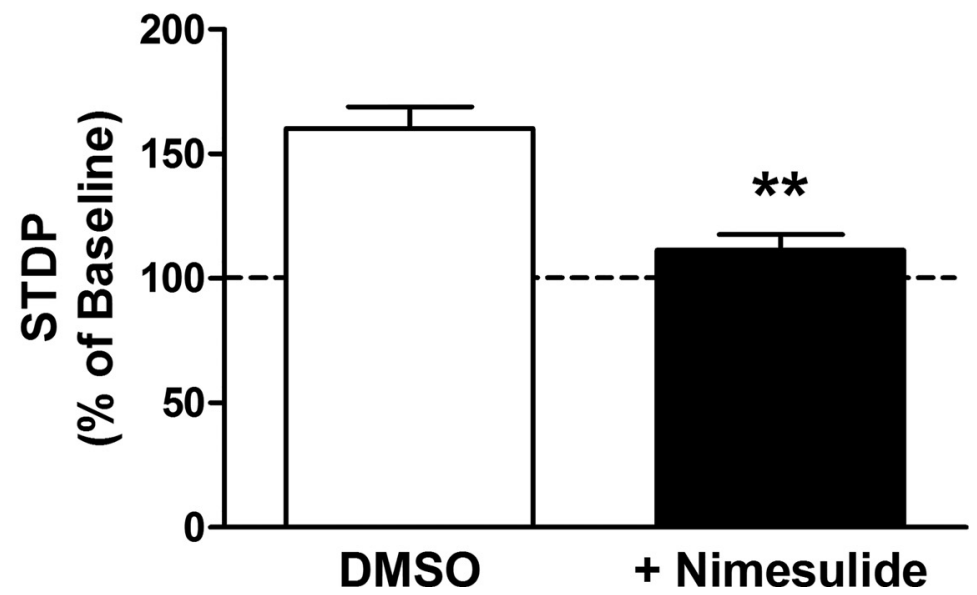

Figure 6. Inhibition of Cox-2 suppresses t-LTP in ascending projection neurons. $A$, Examples of monosynaptic EPSCs evoked by dorsal root stimulation before (black) and after (gray) the administration of the t-LTP pairing protocol in the presence of the selective Cox-2 inhibitor nimesulide. $\boldsymbol{B}$, Current versus time plot illustrating the limited potentiation of EPSC amplitude that occurs when the t-LTP pairing protocol is administered (black bar) in the presence of nimesulide. $\boldsymbol{C}$, The Cox-2 inhibitor significantly reduced the magnitude of t-LTP compared with the vehicle control (DMSO: $n=4$; nimesulide: $n=6 ;{ }^{* *} p=0.009$; MannWhitney test). projection neurons under normal and pathological conditions. Here we demonstrate that $\mathrm{PGE}_{2}$ signaling, occurring downstream of $\mathrm{PLA}_{2}$ and Cox-2 activity, is essential for the generation of t-LTP at primary afferent synapses onto lamina I spino-parabrachial neurons. To our knowledge, this is the first study to implicate prostaglandins in the modulation of STDP within the CNS. More importantly, the results suggest that the gain of ascending nociceptive signaling to the brain is tightly governed by the levels of prostaglandin synthesis within the spinal SDH.

Using a pairing protocol that we have previously shown to be optimal for evoking t-LTP at these synapses ( $\mathrm{Li}$ and Baccei, 2016), our present data clearly demonstrate that the activation of $\mathrm{PLA}_{2}$ and Cox-2 (Figs. 2, 6) are required to evoke the strengthening of afferent inputs that are highly correlated with action potential firing within spinal projection neurons. This agrees with previous studies showing that the activation of $\mathrm{PLA}_{2}$ or Cox-2 following tetanic stimulation potentiates glutamatergic synapses in the CNS via prostaglandin synthesis (Massicotte et al., 1990; O'Dell et al., 1991; Chen et al., 2002; Su et al., 2013), likely via the production of arachidonic acid (Williams et al., 1989; Kato et al., 1991; Luo and Vallano, 1995). Although $\mathrm{AACOCF}_{3}$ inhibits both the $\mathrm{Ca}^{2+}$-dependent and $\mathrm{Ca}^{2+}$-independent subtypes of $\mathrm{PLA}_{2}$ (Street et al., 1993; Ackermann et al., 1995), the prior observation that t-LTP in spinal projection neurons requires elevations in intracellular $\mathrm{Ca}^{2+}$ (Li and Baccei, 2016) would seemingly point to an involvement of the cystolic, $\mathrm{Ca}^{2+}$-dependent form. However, a contribution of $\mathrm{Ca}^{2+}$-independent $\mathrm{PLA}_{2}$ cannot be excluded, as it can also potentiate glutamatergic synapses in the brain (Wolf et al., 1995; Shalini et al., 2014). Interestingly, we found that Cox-2 was constitutively expressed in both neurons (including spino-parabrachial neurons) and microglia within the dorsal horn (Fig. 7). The observation that t-LTP was resistant to minocycline at a concentration that prevented the elevation in MEPSC frequency by fractalkine (Fig. 8) argues against a requirement for microglial activation under naive conditions, and instead raises the possibility that Cox-2 activation within the projection neurons themselves may be instrumental for STDP at primary afferent synapses. Future experiments in which Cox-2 is selectively deleted within projection neurons will be needed to conclusively pinpoint the key site of Cox-2 action within the spinal 

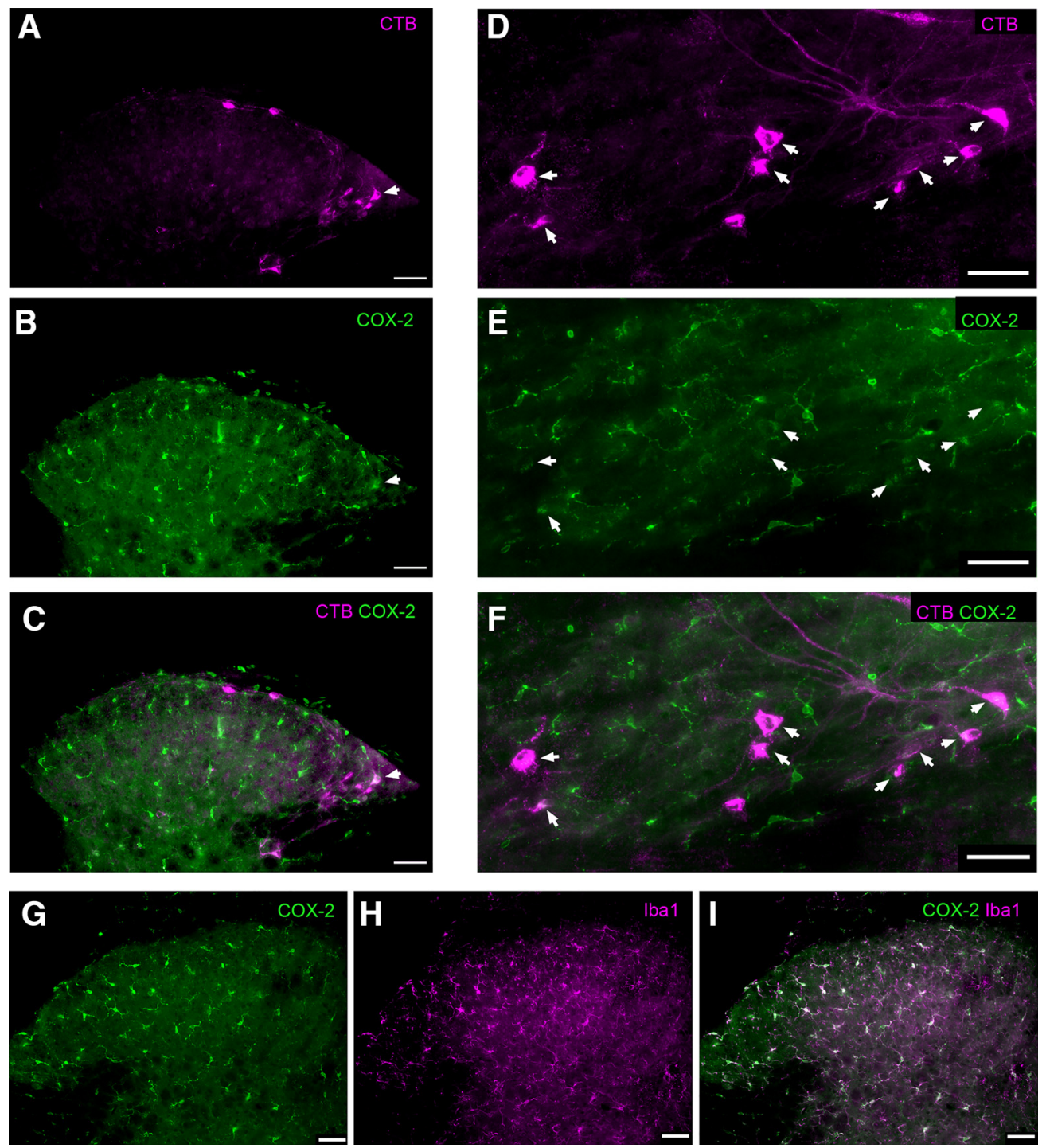

Figure 7. Constitutive expression of Cox-2 in the adult mouse SDH. $A$, Transverse spinal cord section showing the ascending projection neurons that were identified via retrograde transport of CTB previously injected into the parabrachial nucleus. $\boldsymbol{B}$, Same section as in $\boldsymbol{A}$, illustrating immunoreactivity (IR) for Cox-2. Arrowhead indicates a CTB-labeled projection neuron that exhibits Cox-2 IR. C, Merged image (from $\boldsymbol{A}$ and $\boldsymbol{B}$ ) demonstrating the relative distribution of (TB (magenta) and Cox-2 IR (green) in the SDH. The colocalization of CTB and Cox-2 (white) suggests Cox-2 expression within a subset of spinal projection neurons (arrowhead). $\boldsymbol{D}-\boldsymbol{F}$, Horizontal sections of the SDH illustrating additional examples of projection neurons back-labeled with CTB (D) that also possess Cox-2 $\mathbb{I R}(\boldsymbol{E})$, as evidenced by the colocalization seen in $\boldsymbol{F}$ (arrowheads). $\mathbf{G}-\mathbf{I}$, Nonetheless, the majority of Cox-2 IR in the SDH (green) was colocalized with the microglial marker Iba1 (magenta). Scale bars, $50 \mu \mathrm{m}$.

nociceptive network. In addition, microglia can clearly generate $\mathrm{PGE}_{2}$ in the dorsal horn under pathological conditions (Zhao et al., 2007), and the degree to which microglial production of $\mathrm{PGE}_{2}$ may modulate t-LTP in projection neurons after tissue or nerve injury remains unknown.

The spinal dorsal horn contains a variety of $\mathrm{PGE}_{2}$ receptors (EP1-EP4) capable of sensitizing central nociceptive circuits and driving pain hypersensitivity (Minami et al., 1994; Nakayama et al., 2002; Mebane et al., 2003; Bär et al., 2004), with numerous studies demonstrating a specific role for the EP2 subtype in inflammatory pain (Reinold et al., 2005; Hösl et al., 2006). The present data suggest that signaling at the EP2 receptor is required for the production of t-LTP at sensory synapses onto lamina I spino-parabrachial neurons (Fig. $2 C-E$ ). Nonetheless, given that the present study used a single pairing interval $(\Delta t=-10 \mathrm{~ms})$, it remains unclear whether EP2 receptor activation shapes the timing window governing STDP, as has been reported for other $\mathrm{G}_{\mathrm{s}}{ }^{-}$ coupled receptors in the CNS (Zhang et al., 2009). The selective
EP2 receptor agonist butaprost increased the amplitude of monosynaptic primary afferent-evoked EPSCs while decreasing the PPR (Fig. 5), which is highly reminiscent of the changes in presynaptic function seen during t-LTP that are dependent upon a rise in postsynaptic $\mathrm{Ca}^{2+}$ ( $\mathrm{Li}$ and Baccei, 2016). Collectively, these results suggest one possibility that highly correlated firing of sensory afferents and projection neurons leads to the retrograde activation of EP2 receptors located on the presynaptic terminals of sensory neurons, which elevates the probability of glutamate release onto projection neurons and thereby increases synaptic efficacy. However, it is important to note that the available data do not allow us to pinpoint the location of the EP2 receptor (i.e., presynaptic and/or postsynaptic) which is important for t-LTP generation. Indeed, postsynaptic EP2 receptors can drive LTP in other areas of the CNS (Chen et al., 2002), and it is equally possible that the activation of postsynaptic EP2 receptors expressed in projection neurons could trigger the release of another, as yet unidentified, agent that acts as a retrograde messenger to elevate 
A

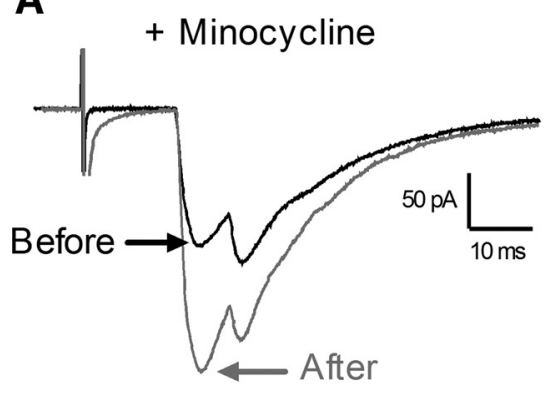

B

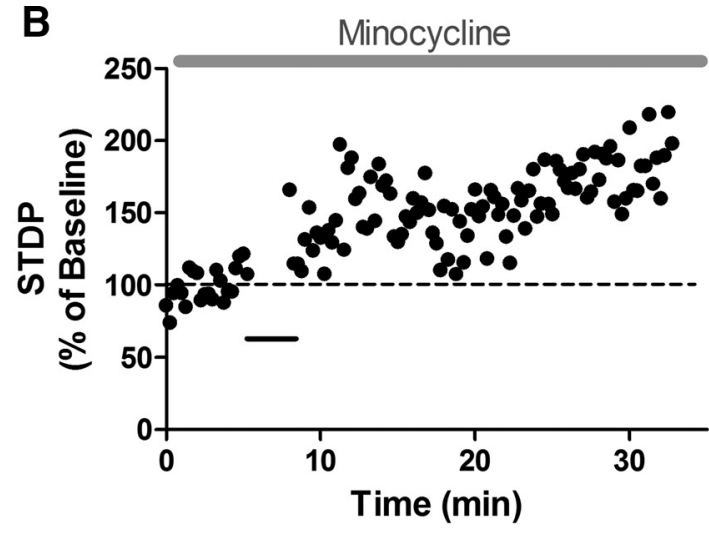

C

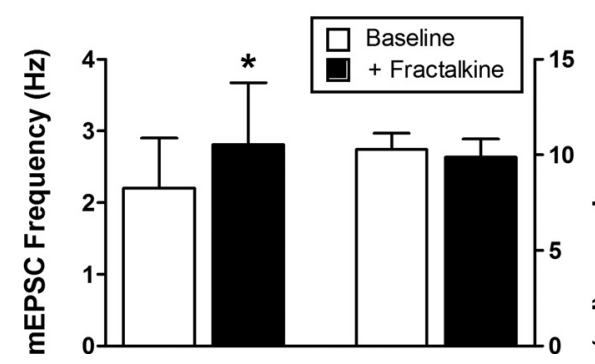

D

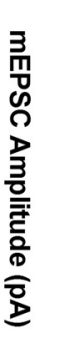

+ Minocycline

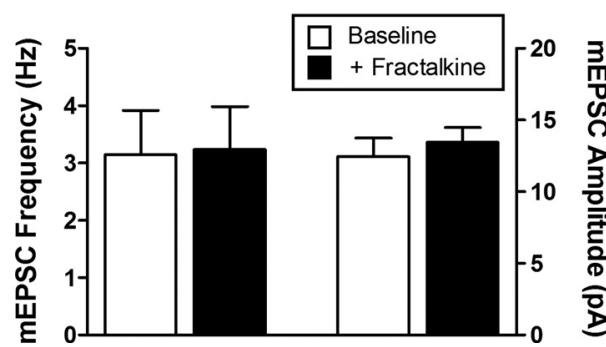

Figure 8. Minocycline fails to prevent t-LTP at primary afferent synapses onto spino-parabrachial neurons. $A$, Representative primary afferent-evoked EPSCs before (black) and after (gray) the administration of the t-LTP pairing protocol in the presence of minocycline to prevent microglial activation. $B$, Current versus time plot demonstrating a significant potentiation in EPSC amplitude following the administration of the t-LTP pairing protocol (black bar) in the continued presence of minocycline. $C$, Bath application of the CX3CR1 ligand fractalkine significantly increased mEPSC frequency in lamina I neurons ( ${ }^{*} p=0.031$; Wilcoxon signed-rank test; left) without influencing mEPSC amplitude ( $p=0.562$; right). $\boldsymbol{D}$, Minocycline blocked the fractalkine-evoked increase in mEPSC frequency within lamina I ( $p=1.0$; Wilcoxon signed-rank test; left).

glutamate release from the presynaptic terminals of sensory neurons in the dorsal horn. In this regard, future studies will explore the degree to which nitric oxide (Ikeda et al., 2006), carbon monoxide (Hawkins et al., 1994), and endocannabinoids (Wang et al., 2014) can mediate retrograde signaling between projection neurons and primary afferents within the SDH. Finally, while EP3 receptors appear to dampen primary afferent transmission (Fig. 5), we also cannot exclude the possibility that other EP receptors (such as EP4) have a role in the potentiation of synaptic efficacy at sensory inputs to ascending spinal projection neurons.

Recent work has demonstrated that surgical incision during a critical period of early life significantly widens the timing window governing t-LTP in adult lamina I spino-parabrachial neurons, which includes an elimination of the requirement that the sensory input precedes action potential firing in the projection neuron ( $\mathrm{Li}$ and Baccei, 2016). It will be of interest to determine whether long-term alterations in prostaglandin synthesis and/or signaling at the EP2 receptor after early-life injury contribute to the more permissive environment for activity-dependent synaptic strengthening in mature projection neurons. Interestingly, the administration of lipopolysaccharide to neonatal rats evokes a persistent upregulation of Cox-2 in the spinal cord (Boissé et al., 2005). Nonetheless, while Cox-2 is upregulated in the spinal cord following peripheral inflammation (Beiche et al., 1996; Samad et al., 2001) and contributes to inflammatory pain (Yamamoto and Nozaki-Taguchi, 1997; Yaksh et al., 2001), prior evidence points to a major role for spinal Cox-1 following hindpaw incision (Yamamoto and Sakashita, 1999; Zhu et al., 2003, 2006). Ultimately, it will be important to elucidate the potential long-term consequences of neonatal tissue damage for the expression of
Cox-1 and Cox-2, as well as regional prostaglandin levels, in the developing spinal dorsal horn.

It has long been known that $\mathrm{PGE}_{2}$ significantly alters the balance between synaptic excitation and inhibition within the spinal pain network. However, prior work has shown that the dominant effect of $\mathrm{PGE}_{2}$ in the dorsal horn is to compromise glycinergic synaptic inhibition (Ahmadi et al., 2002) via action at the $\alpha 3$ subunit of the glycine receptor (GlyR; Harvey et al., 2004). This likely represents a key driver of chronic pain under pathological conditions, given the clear importance of glycinergic neurons (Foster et al., 2015) and GlyR signaling (Acuña et al., 2016) for suppressing mechanical pain sensitivity. Interestingly, these earlier studies reported that $\mathrm{PGE}_{2}$ application failed to influence mEPSC frequency (Ahmadi et al., 2002) or the amplitude of primary afferent-evoked EPSCs (Baba et al., 2001) across the general population of lamina I-II neurons. While the reasons for this apparent discrepancy are unknown, one possibility is that $\mathrm{PGE}_{2}$ modulates glutamatergic signaling in a synapse-selective manner within the SDH. Indeed, while $\mathrm{PGE}_{2}$ consistently evoked potentiation at afferent synapses onto lamina I projection neurons, it failed to evoke a global elevation in glutamate release onto these cells as measured by mEPSCs (Fig. 4). A preferential elevation in the probability of glutamate release at primary afferent terminals onto projection neurons may be insufficient to significantly increase mEPSC frequency, as most mEPSCs recorded in rodent dorsal horn neurons reflect glutamate release from local excitatory interneurons within the region (Baccei et al., 2003). Overall, it appears that $\mathrm{PGE}_{2}$ release can increase the excitability of the $\mathrm{SDH}$ via parallel mechanisms that involve dampening inhibitory tone while strengthening direct primary afferent synapses onto 
ascending projection neurons. Of course, the functional implications of the $\mathrm{PGE}_{2}$-evoked synaptic plasticity within the $\mathrm{SDH}$ for pain perception will ultimately depend on whether such changes also modify nociceptive signaling within the multiple brain circuits known to be instrumental for the sensory, affective, and cognitive dimensions of pain.

In summary, the present findings suggest that $\mathrm{PLA}_{2}-\mathrm{Cox}-2$ activity tightly regulates activity-dependent plasticity at sensory synapses onto the key output neurons of the spinal nociceptive circuit. This suggests that prostaglandins can directly modulate the gain of ascending nociceptive transmission to the brain independently of their known ability to dampen synaptic inhibition within the spinal SDH.

\section{References}

Ackermann EJ, Conde-Frieboes K, Dennis EA (1995) Inhibition of macrophage $\mathrm{Ca}(2+)$-independent phospholipase $\mathrm{A} 2$ by bromoenol lactone and trifluoromethyl ketones. J Biol Chem 270:445-450. CrossRef Medline

Acuña MA, Yévenes GE, Ralvenius WT, Benke D, Di Lio A, Lara CO, Muñoz B, Burgos CF, Moraga-Cid G, Corringer PJ, Zeilhofer HU (2016) Phosphorylation state-dependent modulation of spinal glycine receptors alleviates inflammatory pain. J Clin Invest 126:2547-2560. CrossRef Medline

Ahmadi S, Lippross S, Neuhuber WL, Zeilhofer HU (2002) PGE(2) selectively blocks inhibitory glycinergic neurotransmission onto rat superficial dorsal horn neurons. Nat Neurosci 5:34-40. CrossRef Medline

Baba H, Kohno T, Moore KA, Woolf CJ (2001) Direct activation of rat spinal dorsal horn neurons by prostaglandin E2. J Neurosci 21:17501756. CrossRef Medline

Baccei ML, Bardoni R, Fitzgerald M (2003) Development of nociceptive synaptic inputs to the neonatal rat dorsal horn: glutamate release by capsaicin and menthol. J Physiol 549:231-242. CrossRef Medline

Bär KJ, Natura G, Telleria-Diaz A, Teschner P, Vogel R, Vasquez E, Schaible HG, Ebersberger A (2004) Changes in the effect of spinal prostaglandin E2 during inflammation: prostaglandin E (EP1-EP4) receptors in spinal nociceptive processing of input from the normal or inflamed knee joint. J Neurosci 24:642-651. CrossRef Medline

Beiche F, Scheuerer S, Brune K, Geisslinger G, Goppelt-Struebe M (1996) Up-regulation of cyclooxygenase-2 mRNA in the rat spinal cord following peripheral inflammation. FEBS Lett 390:165-169. CrossRef Medline

Boissé L, Spencer SJ, Mouihate A, Vergnolle N, Pittman QJ (2005) Neonatal immune challenge alters nociception in the adult rat. Pain 119:133-141. CrossRef Medline

Chen C, Magee JC, Bazan NG (2002) Cyclooxygenase-2 regulates prostaglandin E2 signaling in hippocampal long-term synaptic plasticity. J Neurophysiol 87:2851-2857. CrossRef Medline

Chizh BA, Göhring M, TrösterA, Quartey GK, Schmelz M, Koppert W (2007) Effects of oral pregabalin and aprepitant on pain and central sensitization in the electrical hyperalgesia model in human volunteers. Br J Anaesth 98:246-254. CrossRef Medline

Clark AK, Gruber-Schoffnegger D, Drdla-Schutting R, Gerhold KJ, Malcangio M, Sandkühler J (2015) Selective activation of microglia facilitates synaptic strength. J Neurosci 35:4552-4570. CrossRef Medline

Dan Y, Poo MM (2004) Spike timing-dependent plasticity of neural circuits. Neuron 44:23-30. CrossRef Medline

Foster E, Wildner H, Tudeau L, Haueter S, Ralvenius WT, Jegen M, Johannssen H, Hösli L, Haenraets K, Ghanem A, Conzelmann KK, Bösl M, Zeilhofer HU (2015) Targeted ablation, silencing, and activation establish glycinergic dorsal horn neurons as key components of a spinal gate for pain and itch. Neuron 85:1289-1304. CrossRef Medline

Friehs GM, Schröttner O, Pendl G (1995) Evidence for segregated pain and temperature conduction within the spinothalamic tract. J Neurosurg 83: 8-12. CrossRef Medline

Ghilardi JR, Svensson CI, Rogers SD, Yaksh TL, Mantyh PW (2004) Constitutive spinal cyclooxygenase- 2 participates in the initiation of tissue injury-induced hyperalgesia. J Neurosci 24:2727-2732. CrossRef Medline

Harvey RJ, Depner UB, Wässle H, Ahmadi S, Heindl C, Reinold H, Smart TG, Harvey K, Schütz B, Abo-Salem OM, Zimmer A, Poisbeau P, Welzl H, Wolfer DP, Betz H, Zeilhofer HU, Müller U (2004) GlyR alpha3: an essential target for spinal PGE2-mediated inflammatory pain sensitization. Science 304:884-887. CrossRef Medline
Hawkins RD, Zhuo M, Arancio O (1994) Nitric oxide and carbon monoxide as possible retrograde messengers in hippocampal long-term potentiation. J Neurobiol 25:652-665. CrossRef Medline

Hösl K, Reinold H, Harvey RJ, Müller U, Narumiya S, Zeilhofer HU (2006) Spinal prostaglandin E receptors of the EP2 subtype and the glycine receptor alpha3 subunit, which mediate central inflammatory hyperalgesia, do not contribute to pain after peripheral nerve injury or formalin injection. Pain 126:46-53. CrossRef Medline

Ichitani Y, Shi T, Haeggstrom JZ, Samuelsson B, Hökfelt T (1997) Increased levels of cyclooxygenase- 2 mRNA in the rat spinal cord after peripheral inflammation: an in situ hybridization study. Neuroreport 8:2949-2952. CrossRef Medline

Ikeda H, Heinke B, Ruscheweyh R, Sandkühler J (2003) Synaptic plasticity in spinal lamina I projection neurons that mediate hyperalgesia. Science 299:1237-1240. CrossRef Medline

Ikeda H, Stark J, Fischer H, Wagner M, Drdla R, Jäger T, Sandkühler J (2006) Synaptic amplifier of inflammatory pain in the spinal dorsal horn. Science 312:1659-1662. CrossRef Medline

Kato K, Uruno K, Saito K, Kato H (1991) Both arachidonic acid and 1-oleoyl-2-acetyl glycerol in low magnesium solution induce long-term potentiation in hippocampal CA1 neurons in vitro. Brain Res 563:94100. CrossRef Medline

Klein T, Magerl W, Hopf HC, Sandkühler J, Treede RD (2004) Perceptual correlates of nociceptive long-term potentiation and long-term depression in humans. J Neurosci 24:964-971. CrossRef Medline

Klein T, Magerl W, Nickel U, Hopf HC, Sandkühler J, Treede RD (2007) Effects of the NMDA-receptor antagonist ketamine on perceptual correlates of long-term potentiation within the nociceptive system. Neuropharmacology 52:655-661. CrossRef Medline

Larsen RS, Rao D, Manis PB, Philpot BD (2010) STDP in the developing sensory neocortex. Front Synaptic Neurosci 2:9. CrossRef Medline

Li J, Baccei ML (2011) Neonatal tissue damage facilitates nociceptive synaptic input to the developing superficial dorsal horn via NGF-dependent mechanisms. Pain 152:1846-1855. CrossRef Medline

Li J, Baccei ML (2016) Neonatal tissue damage promotes spike timingdependent synaptic long-term potentiation in adult spinal projection neurons. J Neurosci 36:5405-5416. CrossRef Medline

Li J, Kritzer E, Craig PE, Baccei ML (2015) Aberrant synaptic integration in adult lamina I projection neurons following neonatal tissue damage. J Neurosci 35:2438-2451. CrossRef Medline

Luo Y, Vallano ML (1995) Arachidonic acid, but not sodium nitroprusside, stimulates presynaptic protein kinase $\mathrm{C}$ and phosphorylation of GAP-43 in rat hippocampal slices and synaptosomes. J Neurochem 64:1808-1818. Medline

Mantyh PW, Rogers SD, Honore P, Allen BJ, Ghilardi JR, Li J, Daughters RS, Lappi DA, Wiley RG, Simone DA (1997) Inhibition of hyperalgesia by ablation of lamina I spinal neurons expressing the substance P receptor. Science 278:275-279. CrossRef Medline

Massicotte G, Oliver MW, Lynch G, Baudry M (1990) Effect of bromophenacyl bromide, a phospholipase A2 inhibitor, on the induction and maintenance of LTP in hippocampal slices. Brain Res 537:49-53. CrossRef Medline

Mebane H, Turnbach ME, Randich A (2003) Spinal EP receptors mediating prostaglandin E2-induced mechanical hyperalgesia, thermal hyperalgesia, and touch-evoked allodynia in rats. J Pain 4:392-399. CrossRef Medline

Minami T, Nishihara I, Uda R, Ito S, Hyodo M, Hayaishi O (1994) Characterization of EP-receptor subtypes involved in allodynia and hyperalgesia induced by intrathecal administration of prostaglandin E2 to mice. Br J Pharmacol 112:735-740. CrossRef Medline

Nakayama Y, Omote K, Namiki A (2002) Role of prostaglandin receptor EP1 in the spinal dorsal horn in carrageenan-induced inflammatory pain. Anesthesiology 97:1254-1262. CrossRef Medline

Natura G, Bär KJ, Eitner A, Boettger MK, Richter F, Hensellek S, Ebersberger A, Leuchtweis J, Maruyama T, Hofmann GO, Halbhuber KJ, Schaible HG (2013) Neuronal prostaglandin E2 receptor subtype EP3 mediates antinociception during inflammation. Proc Natl Acad Sci U S A 110:1364813653. CrossRef Medline

Nichols ML, Allen BJ, Rogers SD, Ghilardi JR, Honore P, Luger NM, Finke MP, Li J, Lappi DA, Simone DA, Mantyh PW (1999) Transmission of chronic nociception by spinal neurons expressing the substance $\mathrm{P}$ receptor. Science 286:1558-1561. CrossRef Medline 
O’Dell TJ, Hawkins RD, Kandel ER, Arancio O (1991) Tests of the roles of two diffusible substances in long-term potentiation: evidence for nitric oxide as a possible early retrograde messenger. Proc Natl Acad Sci U S A 88:11285-11289. CrossRef Medline

Paxinos G, Franklin K (2012) The mouse brain in stereotaxic coordinates, 4th edition. London: Academic.

Pfau DB, Klein T, Putzer D, Pogatzki-Zahn EM, Treede RD, Magerl W (2011) Analysis of hyperalgesia time courses in humans after painful electrical high-frequency stimulation identifies a possible transition from early to late LTP-like pain plasticity. Pain 152:1532-1539. CrossRef Medline

Randić M, Jiang MC, Cerne R (1993) Long-term potentiation and longterm depression of primary afferent neurotransmission in the rat spinal cord. J Neurosci 13:5228-5241. CrossRef Medline

Reinold H, Ahmadi S, Depner UB, Layh B, Heindl C, Hamza M, Pahl A, Brune K, Narumiya S, Müller U, Zeilhofer HU (2005) Spinal inflammatory hyperalgesia is mediated by prostaglandin $\mathrm{E}$ receptors of the $\mathrm{EP} 2$ subtype. J Clin Invest 115:673-679. CrossRef Medline

Ruscheweyh R, Wilder-Smith O, Drdla R, Liu XG, Sandkühler J (2011) Long-term potentiation in spinal nociceptive pathways as a novel target for pain therapy. Mol Pain 7:20. CrossRef Medline

Samad TA, Moore KA, Sapirstein A, Billet S, Allchorne A, Poole S, Bonventre JV, Woolf CJ (2001) Interleukin-1beta-mediated induction of Cox-2 in the CNS contributes to inflammatory pain hypersensitivity. Nature 410: 471-475. CrossRef Medline

Sandkühler J, Liu X (1998) Induction of long-term potentiation at spinal synapses by noxious stimulation or nerve injury. Eur J Neurosci 10:24762480. CrossRef Medline

Sang N, Zhang J, Marcheselli V, Bazan NG, Chen C (2005) Postsynaptically synthesized prostaglandin E2 (PGE2) modulates hippocampal synaptic transmission via a presynaptic PGE2 EP2 receptor. J Neurosci 25:98589870. CrossRef Medline

Shalini SM, Chew WS, Rajkumar R, Dawe GS, Ong WY (2014) Role of constitutive calcium-independent phospholipase A2 beta in hippocampo-prefrontal cortical long term potentiation and spatial working memory. Neurochem Int 78:96-104. CrossRef Medline

Spiller WG, Martin E (1912) The treatment of persistent pain of organic origin in the lower part of the body by division of the anterolateral column of the spinal cord. JAMA 58:1489-1490. CrossRef

Street IP, Lin HK, Laliberté F, Ghomashchi F, Wang Z, Perrier H, Tremblay NM, Huang Z, Weech PK, Gelb MH (1993) Slow- and tight-binding inhibitors of the $85-\mathrm{kDa}$ human phospholipase A2. Biochemistry 32: 5935-5940. CrossRef Medline

Su LD, Wang DJ, Yang D, Shen Y, Hu YH (2013) Retrograde cPLA2alpha/ arachidonic acid/2-AG signaling is essential for cerebellar depolarizationinduced suppression of excitation and long-term potentiation. Cerebellum 12:297-299. CrossRef Medline

Svendsen F, Tjølsen A, Hole K (1997) LTP of spinal A beta and C-fibre evoked responses after electrical sciatic nerve stimulation. Neuroreport 8:3427-3430. CrossRef Medline

Ting JT, Daigle TL, Chen Q, Feng G (2014) Acute brain slice methods for adult and aging animals: application of targeted patch clamp analysis and optogenetics. Methods Mol Biol 1183:221-242. CrossRef Medline
Todd AJ (2010) Neuronal circuitry for pain processing in the dorsal horn. Nat Rev Neurosci 11:823-836. CrossRef Medline

Wang DJ, Su LD, Wang YN, Yang D, Sun CL, Zhou L, Wang XX, Shen Y (2014) Long-term potentiation at cerebellar parallel fiber-Purkinje cell synapses requires presynaptic and postsynaptic signaling cascades. J Neurosci 34:2355-2364. CrossRef Medline

Wang H, Bolognese J, Calder N, Baxendale J, Kehler A, Cummings C, Connell J, Herman G (2008) Effect of morphine and pregabalin compared with diphenhydramine hydrochloride and placebo on hyperalgesia and allodynia induced by intradermal capsaicin in healthy male subjects. J Pain 9:1088-1095. CrossRef Medline

Williams JH, Errington ML, Lynch MA, Bliss TV (1989) Arachidonic acid induces a long-term activity-dependent enhancement of synaptic transmission in the hippocampus. Nature 341:739-742. CrossRef Medline

Wolf MJ, Izumi Y, Zorumski CF, Gross RW (1995) Long-term potentiation requires activation of calcium-independent phospholipase A2. FEBS Lett 377:358-362. CrossRef Medline

Yagami T, Koma H, Yamamoto Y (2016) Pathophysiological roles of cyclooxygenases and prostaglandins in the central nervous system. Mol Neurobiol 53:4754-4771. CrossRef Medline

Yaksh TL, Dirig DM, Conway CM, Svensson C, Luo ZD, Isakson PC (2001) The acute antihyperalgesic action of nonsteroidal, anti-inflammatory drugs and release of spinal prostaglandin E2 is mediated by the inhibition of constitutive spinal cyclooxygenase-2 (COX-2) but not COX-1. J Neurosci 21:5847-5853. CrossRef Medline

Yamagata K, Andreasson KI, Kaufmann WE, Barnes CA, Worley PF (1993) Expression of a mitogen-inducible cyclooxygenase in brain neurons: regulation by synaptic activity and glucocorticoids. Neuron 11:371-386. CrossRef Medline

Yamamoto T, Nozaki-Taguchi N (1997) Role of spinal cyclooxygenase (COX)-2 on thermal hyperalgesia evoked by carageenan injection in the rat. Neuroreport 8:2179-2182. CrossRef Medline

Yamamoto T, Sakashita Y (1999) The role of the spinal opioid receptor like1 receptor, the NK-1 receptor, and cyclooxygenase- 2 in maintaining postoperative pain in the rat. Anesth Analg 89:1203-1208. CrossRef Medline

Zhang HM, Zhou LJ, Hu XD, Hu NW, Zhang T, Liu XG (2004) Acute nerve injury induces long-term potentiation of C-fiber evoked field potentials in spinal dorsal horn of intact rat. Sheng Li Xue Bao 56:591-596. Medline

Zhang JC, Lau PM, Bi GQ (2009) Gain in sensitivity and loss in temporal contrast of STDP by dopaminergic modulation at hippocampal synapses. Proc Natl Acad Sci U S A 106:13028-13033. CrossRef Medline

Zhao P, Waxman SG, Hains BC (2007) Extracellular signal-regulated kinase-regulated microglia-neuron signaling by prostaglandin E2 contributes to pain after spinal cord injury. J Neurosci 27:2357-2368. CrossRef Medline

Zhu X, Conklin D, Eisenach JC (2003) Cyclooxygenase-1 in the spinal cord plays an important role in postoperative pain. Pain 104:15-23. CrossRef Medline

Zhu X, Vincler MA, Parker R, Eisenach JC (2006) Spinal cord dynorphin expression increases, but does not drive microglial prostaglandin production or mechanical hypersensitivity after incisional surgery in rats. Pain 125:43-52. CrossRef Medline 